\title{
Analisis Kebutuhan Materi Mata Kuliah Teknologi Informasi dan Komunikasi untuk Guru Bahasa pada Program Magister (S2) Pendidikan Bahasa Indonesia FKIP Universitas Bengkulu
}

\author{
Gumono \\ gumono@unib.ac.id \\ FKIP Universitas Bengkulu
}

\begin{abstract}
Abstrak. Penelitian ini bertujuan mendeskripsikan secara komprehensif kebutuhan materi mata kuliah Teknologi Informasi dan Komunikasi Untuk Guru Bahasa pada Program Magister (S2) Pendidikan Bahasa Indonesia FKIP Universitas Bengkulu. Metode penelitian yang diterapkan adalah desain penelitian deskriptif kualitatif. Responden penelitian berjumlah 32 orang mahasiswa program Magister (S2) Pendidikan Bahasa Indonesia. Hasil penelitian: 1) materi yang disajikan pada mata kuliah TIK untuk Guru Bahasa belum memenuhi kebutuhan belajar dan pengembangan profesional guru (responden). 2) guru responden menginginkan materi belajar yang mendukung studi dan karir mereka. 3) responden membutuhkan materi belajar meliputi: aplikasi Microsoft Office/sejenis, aplikasi terkait pembelajaran daring, dan aplikasi penunjang penelitian.
\end{abstract}

Kata Kunci: analisis kebutuhan, bahan ajar, pembelajaran berbasis TIK

\section{Pendahuluan}

Salah satu pertimbangan dalam pengembangan rencana pembelajaran yang sehat adalah adanya analisis kebutuhan anak didik. Prosedur pengumpulan data untuk identifikasi kebutuhan riil umum disebut analisis kebutuhan. Analisis kebutuhan sebagai salah satu tahapan dalam perencanaan program pembelajaran mulai dikenal tahun 1960-an yang menjadi bagian integral pendekatan sistem dalam pengembangan kurikulum (Stufflebeam et al., 1985).

Analisis kebutuhan pertama kali diperkenalkan ke dalam pengajaran bahasa khususnya bahasa Inggris untuk tujuan khusus (ESP/english for spesifik purposes). Memperhatikan keberhasilannya, permintaan analisis kebutuhan untuk program bahasa khusus tumbuh pesat dan menerapkan prosedur analisis yang semakin terstruktur. Prosedur analisis kebutuhan dalam pembelajaran selanjutnya menjadi langkah baku yang harus ditempuh sebelum seseorang/lembaga/pemerintah mengembangkan sebuah program.

Perkembangan kondisi empiris yang terus berjalan, menghendaki inovasi dan pembaruan program pendidikan yang terus-menerus secara simultan. Hal ini mengharuskan adanya analisis kebutuhan yg terus-menerus pula, agar program yg dirumuskan berdaya guna. Kondisi empiris dimaksud adalah perkembangan ipteks yang kini memasuki era Revolusi Industri 4.0. Istilah industri 4.0 diawali dari proyek yang diinisiasi oleh pemerintah Jerman untuk promosi komputerisasi pada manufaktur (Yahya, 2018). Jerman adalah negara yang mempelopori roadmap (grand design) penerapan ekonomi digital. Era revolusi industri ini acap pula disebut dengan istilah Revolusi digital/Era disrupsi. Disrupsi dalam bahasa indonesia dimaknai tercabut dari akarnya. Renald Kasali (2018) mengartikan disrupsi sebagai inovasi. Dengan demikian, disrupsi bisa dimaknai sebagai perubahan yang mendasar atau fundamental. Pada era ini, terjadi perubahan mendasar yang bersifat masif, dimana teknologi masuk ke setiap bidang kehidupan masyarakat. 
Era disrupsi dapat dicirikan adanya perubahan masif, cepat, berpola sulit ditebak (volatility). Cepatnya perubahan menyebabkan ketidak pastian (ancertainty), terjadi konektifitas yang komplek antar faktor penyebab (complexity), dan arah perubahan yang ambigu (ambiguity), sering disingkat VUCA (RISTEKDIKTI, 2018). Di Indonesia, pada masa ini TIK merasuk menjadi basis perkehidupan manusia, tak terkecuali bidang pendidikan. Perkembangannya sangat cepat, bahkan dunia kini beranjak masuk ke era society 5.0. Dalam Revolusi Industri 4.0, melalui teknologi komputasi dan big data menjadikan dunia seakan tanpa batas. Internet dan teknologi digital menjadi tulang punggung pergerakan dan konektivitas manusia dan mesin.

Pemerintah Republik Indonesia dengan rumusan peta jalan Making Indonesia 4.0, saat ini sedang menerapkan langkah langkah strategis, merespon disrupsi informasi ini. Ini dilakukan untuk mengakselerasi perwujudan visi nasional yang telah dirumuskan untuk mengambil manfaat dari revolusi industri 4.0. Diantara Making Indonesia 4.0 adalah upaya mewujudkan Indonesia menjadi satu dari 10 besar negara yang memiliki perekonomian terkuat pada 2030 (Satya, 2018). Salah satu prioritas dari program Making Indonesia 4.0 adalah meningkatkan mutu sumber daya manusia.. Dalam rangka hal tersebut, kurikulum pendidikan akan dirombak dengan fokus mengintegrasikan STEAM (Science, Technology, Engineering, the Arts, dan Mathematics), menyesuaikan kebutuhan industri masa depan. Pemerintah menguatkan kerjasama dengan dunia industri dan asing untuk peningkatan kualitas sekolah vokasional, dan terus meningkatkan program mobilitas tenaga kerja dunia untuk mendayagunakan suplai sumber daya manusia SDM serta mempercepat alih pengetahuan dan kompetensi (Hartanto, 2018).

Pada era ini, lembaga pendidikan wajib membekali anak didik kompetensi yang dibutuhkan pada perikehidupan abad 21 (21st Century Skills). Antara lain, keterampilan berfikir kritis, problem solver, kreatif dan inovatif serta kemampuan berkomunikasi dan berkolaborasi. Selain itu, juga dibutuhkan kecakapan mencari, mengelola, dan menyampaikan informasi, serta wajib terampil mendayagunakan teknologi informasi dan komunikasi. Di Indonesia, ada tiga isu pendidikan sentral yang menjadi fokus pendidikan, yakni pendidikan karakter, pendidikan vokasi, merangsang daya inovasi (Wibawa, 2018).

Bukan hanya siswa, guru/dosen juga harus menguasai kompetensi ini. Akan menjadi anomali, jika peserta didik dituntut memiliki ketrampilan abad 21, sedangkan guru/dosennyatidak siap. Tidak ada pilihan lain, guru/dosen wajib menguasai kompetensi dasar yang kuat, dan memiliki kecakapan: berpikir kritis, kreatif, komunikatif dan koloboratif. Interaksi belajar mengajar yang diciptakan guru/dosen harus mampu mengembangkan suasana akademik yang sesuai kebutuhan psikologis anak didik, meliputi: Needs for competence interaksi belajar mengajar harus mampu membuat mahasiswa merasa mampu/bisa. Pendidik perlu memberi reward atas hasil belajar anak. Needs for Autonomy, setiap peserta didik butuh 'otonomi' dengan cara pendidik memberikan kebebasan (freedom) dan kepercayaan (trust). Needs for relatedness, peserta didik butuh merasa diri sebagai bagian dari kelompok, serta ada interaksi dalam kelompok tersebut. Proses belajar mengajar harus dapat memupuk kolegialitas dan saling support dalam kelompok. Pembelajaran wajib membekali siswa untuk 'sustainable learning', sehingga mereka bisa melalui era disrupsi dan masuk era baru yang sering dinamai abundant era (Risdianto, 2019).

Kondisi empiris lain yang mempengaruhi dunia pendidikan adalah munculnya pandemi global yang disebabkan oleh corona virus pada tahun 2020 yang kemudian dikenal luas dengan 
istilah Covid-19 (Corona virus diseases 2019). Munculnya covid-19 yang menjadi epidemi pada akhir tahun 2019 di Wuhan, Tiongkok telah menyentakkan kesadaran dunia internasional betapa berbahanya virus ini. Betapa tidak, begitu cepat dan masifnya virus ini menyebar, dimana dalam kurun waktu tiga bulan kurang, covid-19 telah menjangkiti sebanyak 126.000 orang lebih, di 123 negara, tersebar di Eropa, Asia, Amerika Serikat, hingga Afrika. Puncaknya kemudian WHO mengumumkan status yang awalnya epidemi di Wuhan Tiongkok itu, menjadi pandemik global pada hari Rabu 11 Maret 2020 (Putri, 2020).

Kondisi-kondisi empiris di atas memaksa dunia pendidikan, khususnya guru/dosen sebagai aktor utama di kelas, untuk menyesuaikan diri. Guru tidak bisa menerapkan metodologi pembelajaran konvensional di kelas. Guru wajib menerapkan pembelajaran berbasis TIK atau blended learning. Penelitian ini akan mendeskripsi secara komprehensif kebutuhan guru bahasa Indonesia dalam pembelajaran yang dilaksanakan berbasis TIK. Kebutuhan guru tersebut kemudian akan disajikan dalam mata kuliah Teknologi Informasi dan Komunikasi untuk Guru Bahasa yang disajikan kurikulum pada Magister (S2) Pendidikan Bahasa Indonesia FKIP Universitas Bengkulu

Salah satu syarat mendasar pengembangan materi ajar adalah analisis kebutuhan pembelajar. Langkah-langkah mengumpulkan informasi tentang apa yang dibutuhkan sekelompok subyek biasa disebut analisis kebutuhan. Dalam konteks pembelajaran, analisis kebutuhan dimaknai sebagai usaha untuk mencari dan menggambarkan kebutuhan-kebutuhan dan keinginan peserta didik dalam proses pembelajaran. Analisis kebutuhan sebagai langkah awal dan diperlukan untuk membuat perencanaan program pendidikan adalah bagian dari pendekatan sistem dalam pengembangan kurikulum untuk memenuhi prinsip akuntabilitas pendidikan.

Dalam konteks pembelajaran bahasa, Kathleen Graves menyatakan analisis kebutuhan adalah aktivitas sistematis dan proses yang berlangsung simultan untuk menjaring informasi tentang apa yang dibutuhkan siswa, kecenderungannya, memaknai, kemudian mengembangkan bahan ajar agar sesuai dengan tujuan belajar (Graves, 2000). Menurut Graves, tujuan utama analisis kebutuhan berbahasa adalah untuk membantu mendapatkan informasi yang dibutuhkan tentang kemampuan siswa.

Sementara itu, lebih khusus Jack C. Richards dalam pembelajaran bahasa, analisis kebutuhan bertujuan: (1) identifikasi kebutuhan keterampilan berbahasa siswa yang setelah selesai pendidikan akan mereka manfaatkan untuk bekerja, misalnya sebagai manajer pemasaran, pemandu wisata, dan siswa, (2) memastikan ketepatan bahan ajar dengan kebutuhan siswa, (3) menentukan siswa dalam satu kelompok yang sangat memerlukan latihan kecakapan berbahasa tertentu, (4) mengenali peluang seseorang dalam kelompok, (5) identifikasi kesenjangan antara potensi yang dimiliki siswa dengan kemampuan yang mereka kuasai, dan (6) mendapatkan informasi tentang permasalahan khusus yang dimiliki siswa (Jack C. Richards, 2000). Tujuan analisis kebutuhan adalah (1) mendapatkan mekanisme untuk mendapatkan masukan materi, desain dan penyebaran ( program bahasa dengan melibatkan siswa, guru, administrator dan kepala (proyek) dalam proses perencanaan, (2) mengidentifikasi kebutuhan bahasa, agar dapat dimasukkan dalam pengembangan tujuan dan materi program bahasa, dan (3) mendapatkan data yang bisa digunakan sebagai acuan evaluasi program bahasa.

Hyland menjelaskan bahwa analisis kebutuhan digunakan untuk teknik mengumpulkan 
dan analisis informasi tentang dengan kebutuhan peserta didik: perangkat yang dapat digunakan untuk membentuk sebuah program pembelajaran. Analisis kebutuhan adalah proses simultan sehingga pendidik bisa melakukan penyesuaian proses pembelajaran agar menjnadi lebih baik, untuk mengakomodasi kebutuhan belajar peserta didik (Hyland, 2003).

Ada beberapa hal yang harus dipertimbangkan dalam analisis kebutuhan (Nation \& McAllister, 2010), yakni: Pertama, secara prinsip harus diarahkan pada tujuan dan isi mata pelajaran. Kedua, mengungkap prior knowledge peserta didik dan apa yang mereka perlu ketahui. Ketuga, memastikan bahwa subyek mata pelajaran memuat materi yang relevan dan berguna bagi siswa. Analisis kebutuhan yang baik harus memuat pertanyaan yang benar dan mampu menggali jawaban dengan efektif.

Gagasan yang disampaikan Nation dan Macalister sejalan dengan penjelasan Hutchinson dan Waters mengenai analisis kebutuhan. Hutchinson dan Waters membedakan kebutuhan menjadi kebutuhan target (target needs) dan kebutuhan belajar (learning needs). Kebutuhan target berkaitan dengan apa yang harus dilakukan peserta didik untuk dapat berperilaku pada situasi target, sedangkan kebutuhan belajar berkaitan dengan apa yang perlu dilakukan peserta didik untuk belajar. Analisis kebutuhan target memperhatikan tiga aspek, yaitu aspek keharusan (necessities), aspek kekurangan (lack), dan aspek keinginan (want)(Hutchinson et al., 1987).

\section{Metode}

Desain penelitian yang digunakan adalah deskriptif kualitatif dengan menerapkan teknik pengumpulan data survey dan wawancara mendalam. Penelitian dilaksanakan di Program Magister (S2) Pendidikan Bahasa Indonesia FKIP Universitas Bengkulu. Waktu pelaksanaan penelitian adalah pada semester ganjil tahun akademik 2020/2021. Sumber data penelitian adalah mahasiswa Program Magister (S2) Pendidikan Bahasa Indonesia FKIP Uiversitas Bengkulu yang mengambil MK Teknologi Informasi dan Komunikasi untuk Guru Bahasa. Data dikumpulkan dengan teknik survey dan indepth interview (wawancara mendalam. Analisis data dilaksanakan dengan tekik analisis data Miles \& Huberman (Miles et al., 2014).

\section{Hasil dan Pembahasan \\ Hasil}

Survey dan indepth interview dilakukan kepada responden mahasiswa Program Magister (S2) Pendidikan Bahasa Indonesia FKIP Universitas Bengkulu. Jumlah responden sebanyak 32 orang guru yang sedang menempuh pendidikan magister. Analisis kebutuhan ini dilaksanakan untuk melengkapi data kebutuhan bahan ajar MK TIK untuk Guru Bahasa, yang sebagian telah diperoleh melalui kajian pustaka dan pengamatan lapangan. Instrumen yang digunakan pada studi kebutuhan ini adalah kuesioner yang disebarkan kepada 32 orang responden. Semua responden mengembalikan angket yang diserahkan. Tahapan penelitian ini dilaksanakan pada bulan Agustus s. d. Oktober 2020.

Kuesioner yang disebarkan berisi pernyataan-pernyataan yang diikuti oleh empat pilihan jawaban, yaitu: tidak setuju/tidak penting, kurang setuju/kurang penting, setuju/penting, dan sangat setuju/sangat penting. Indikator bobot pilihan adalah: 
1. Tidak Setuju/Tidak Penting adalah jika persentase tingkat kebutuhan terhadap pernyataan ini berkisar antara $0 \%$ s. d. $25 \%$.

2. Kurang Setuju/Kurang Penting adalah jika persentase tingkat kebutuhan terhadap pernyataan ini berkisar antara $26 \%$ s. d. $50 \%$.

3. Setuju/Penting adalah jika persentase tingkat kebutuhan terhadap pernyataan ini berkisar antara $51 \%$ s. d. $75 \%$.

4. Sangat Setuju/Sangat Penting adalah jika persentase tingkat kebutuhan terhadap pernyataan ini lebih dari $75 \%$.

Kuesioner yang telah disebar dan diisi oleh responden, kemudian dikumpulkan dan ditabulasi untuk dianalisis. Hasil analisis studi kebutuhan dilaporkan sebagai berikut.

Bagian awal kuesioner berisi tentang ketersediaan dan kesesuaian bahan ajar MK TIK untuk Guru Bahasa yang tersedia. Pernyataan pertama berbunyi “ Kesesuaian materi ajar yang disajikan dalam mata kuliah TIK untuk Guru Bahasa”. Terhadap pernyataan ini, 47\% guru menyatakan tidak setuju dan $40 \%$ guru menyatakan kurang setuju, dan hanya $13 \%$ responden saja yang menyatakan setuju. Hal ini dapat dimaknai bahwa materi ajar perkuliahan yang disajikan saat ini belum memadai/sesuai dengan kebutuhan .

Sebagian besar guru responden menyatakan tidak setuju (13\%) dan kurang setuju (43\%) bahwa Bahan ajar MK TIK untuk Guru Bahasa yang ada mencukupi kebutuhan belajar mahasiswa. Dengan kata lain, sebagian besar responden yang disurvey menyatakan bahwa materi ajar yang ada tidak mencukupi kebutuhan belajar mahasiswa. Hal ini, disebabkan oleh kesesuaian bahan ajar yang ada dengan kebutuhan siswa. Mayoritas responden menyatakan tidak setuju (33\%) dan kurang setuju (30\%) terhadap pernyataan "Bahan ajar MK TIK untuk Guru Bahasa yang ada sesuai dengan kebutuhan" Sisanya 13\% responden menyatakan setuju dan 23\% menyatakan sangat setuju terhadap pernyataan tersebut.

Hasil survey juga memperlihatkan bahwa bahan ajar yang tersedia saat ini menurut responden kurang sesuai dengan pengetahuan awal mereka (43\%). Sebagian besar responden sangat setuju (57\%) jika dikembangkan bahan ajar MK TIK untuk Guru Bahasa direvisi dengan mempertimbangkan pengetahuan awal mereka. Alasan responden atas pendapatnya tersebut, bahan ajar yang melibatkan pengetahuan awal yang dimiliki mahasiswa akan lebih mudah di konstruksi menjadi bangun pengetahuan yang lebih besar. Pengetahuan yang terbangun tidak bersifat segmental.

Segmen pertama kuesioner studi kebutuhan ini memperlihatkan bahwa responden menyatakan bahwa bahan ajar yang disajikan selama ini, tidak mencukupi dan kurang sesuai dengan kebutuhan belajar mereka, baik untuk kepentingan belajar maupun pengembangan karir profesional mereka. Oleh karenanya, mereka mengharapkan ada revisi materi ajar yang disajikan pada mata kuliah TIK untuk Guru Bahasa.

Segmen kedua kuesioner berisi pernyataan dan pertanyaan tentang topik materi ajar yang dibutuhkan responden (need). Pada bagian ini, peneliti menjaring kebutuhan dan keinginan guru tentang profil materi ajar yang disajikan pada MK TIK untuk Guru Bahasa.

Seluruh responden menyatakan bahwa materi ajar TIK yang mendukung/membekali mereka kecakapan melaksanakan pembelajaran berbasis teknologi informasi dan menunjang penyelesaian studi pada program magister adalah sangat penting $(77 \%)$ dan penting $(23 \%)$ bagi 
mereka. Hal ini didasari kesadaran pendidikan dalam kondisi khusus darurat seperti saat ini membutuhkan kecakan penguasaan teknologi informasi untuk melaksanakan pembelajaran. Guru, siswa, dan orang tua secara umum menyepakati bahwa peran teknologi informasi dan komunikasi saat ini tak dapat disangkal. Selain dapat meretas keterbatasan petemuan fisik (keharusan melaksanakan social distancing), pemanfaatan teknologi informasi dalam pembelajaran juga memberikan variasi metode pembelajaran yang variatif dan atraktif.

Responden juga mengharapkan materi ajar MK TIK untuk Guru Bahasa dikembangkan berdasarkan perkembangan teknologi informasi terkini dan yang secara praktis diterapkan oleh guru dalam melaksanakan kinerja profesionalnya sehari-hari. Sebanyak $40 \%$ responden menyatakan hal itu sangat penting, 30\% menyatakan penting, 23\% menyatakan kurang penting, dan sisanya menyatakan tidak penting. Responden sangat mengharapkan materi ajar MK TIK untuk Guru Bahasa menyajikan contoh-contoh praktis yang dapat diikuti dan dipraktikkan langsung.

Pilihan topik yang diinginkan guru dilatar-belakangi oleh kebutuhan profesional mereka dan pengalaman mereka mengajar. Topik yang dipilih responden, seperti terlihat pada tabel di atas, diharapkan bisa disajikan dalam MK TIK untuk Guru Bahasa. Topik-topik yang diinginkan oleh sebagian besar responden, yang terlihat pada tabel di atas, dipertimbangkan oleh peneliti untuk menjadi topik pilihan yang akan dikembangkan menjadi bahan ajar MK TIK untuk Guru Bahasa.

Semua responden menempatkan tiga aplikasi Microsoft Office sebagai materi yang harus disajikan sebagai kajian dalam MK TIK untuk Guru Bahasa. Latar belakang pilihan ini adalah karena ketiga aplikasi tersebut menjadi aplikasi yang dibutuhkan responden dalam kehidupan sehari-hari. Aplikasi Microsoft Office menjadi pilihan wajib dipelajari karena responden aplikasi perkantoran pertama yang sudah sangat diakrabi responden sejak jenjang sekolah dasar/menengah adalah Microsof Office. Responden belum terbiasa tidak akrab dengan aplikasi perkantoran lain, misalnya WPS Office, Open Office, atau Libre Office. Semua responden menyatakan tidak penting untuk mempelajari WPS Office, Open Office, atau Libre Office

Aplikasi perkantoran yang menurut responden wajib dimasukkan sebagai bahan ajar meliputi yang berikut:

1. MICROSOFT WORD
a) Menulis dengan MS Word
b) Format Dokumen
c) Pengaturan Page Layout dan Design
d) Insert Tabel, Grafik dan Gambar
e) Pengaturan References
f) Mail Merge dan Mencetak Dokumen

2. MICROSOFT EXCEL
a) Pengenalan Microsoft Office Excel
b) Mengelola Worksheet
c) Fungsi dan Formula
d) Mengelola Data
e) Grafik Dan Mencetak Hasil

3. MICROSOFT POWERPOINT

a) Mengenal Microsoft Powerpoint

b) Format Dokumen dan Bekerja dengan Slide 
c) Menambahkan Gambar, Clipart, Suara dan Video

d) Tabel, Grafik Dan Diagram

e) Theme Dan Template

f) Membuat Transition dan Animation

Responden juga berharap bahan ajar MK TIK untuk Guru Bahasa menyajikan materi terkait Zoom Cloud Meeting untuk Pembelajaran. Alasan responden, Zoom Meeting sangat dibutuhkan/sangat membantu guru responden melaksanakan pembelajaran tatap muka maya, pada pembelajaran di masa pandemi yang sedang berlangsung. Seperti diketahui, pada tahun 2020 pelaksanaan pembelajaran mengikuti kebijakan nasional untuk mencegah penyebaran virus corona, yang antara lain mewajibkan pemberlakuan kebijakan jaga jarak (physical distancing), yang berimplikasi pada larangan melaksanakan pembelajaran langsung di sekolah. Sebagai pengganti, dilaksanakan pembelajaran dalam jaringan (online). Zoom Meeting merupakan salah satu platform rapat dalam jaringan (online meeting) yang banyak dipilih oleh guru.

Platform pertemuan dalam jaringan lain yang ditawarkan oleh Google, yang merupakan bagian dari paket Google yaitu Google Meet, tidak terlalu diminati oleh responden. Ada 63\% responden yang menyatakan Google Meet penting dipelajari. Sisanya, 27\% menyatakan penting, dan $10 \%$ menyatakan tidak penting. Pilihan utama bukan Google Meet, karena responden menyatakan bahwa sudah terbiasa memanfaatkan platform lain.

Media presentasi yang dipilih hampir semua responden adalah Microsoft Power Point. Pada saat diberi pilihan Prezi sebagai alternatif media presentasi yang dipelajari, responden cenderung menolak. Hanya 10\% responden yang memilih Prezi untuk dipelajari, dengan alasan aplikasi ini berat dan rumit. Responden lebih mengharapkan pendalaman kustomisasi pengaya Power Point yang dipelajari dan latihkan.

Media pembelajaran berbasis TIK lain yang ditawarkan kepada responden yakni Sparkol VideoScribe, Media Virtual Reality, maupun Augmented Reality untuk Pembelajaran, juga tidak disepakati sebagian besar responden untuk disajikan dalam MK TIK untuk Guru Bahasa. Alasan bahwa dasar pengetahuan mereka terkait TIK yang tidak memadai menjadi latar belakang mereka menganggap dua media pembelajaran tersebut penting dipelajari. Responden juga menganggap penggunaan sistem manajemen pembelajaran (learning magement system) berbasis Moodle tidak penting dipelajari. Responden masih merasa asing dengan LMS.

Fasilitas yang disediakan Google, yang sudah sangat dikenali hanya surel berekstensi Gmail. Fasilitas lain belum akrab dan dimanfaatkan secara efektif oleh responden. Survey menunjukkan bahwa responden sebagian besar berminat mempelajari berbagai fitur Google untuk meningkatkan produktivitas kerja akademis dan profesional mereka. Fitur dimaksud meliputi: a. Google Mail; b. Google Form; c. Google Doc; d. Google Drive; e. Google Classroom; f. Google Photos; g. Youtube; dan h. Google Meet.

Aplikasi pengolah data kuantitatif dalam penelitian seperti SPSS atau minitab kurang diminati responden. Hanya $25 \%$ responden yang menganggap sangat penting dan $30 \%$ menyatakan penting mempelajari program aplikasi statistik untuk penelitian ilmu-ilmu sosial ini. Alasan yang disampaikan responden, dalam dunia keguruan sebagian besar penelitian dilaksanakan dalam desain penelitian kualitatif. Seandainya membutuhkan pengolahan statistik sederhana, responden menyatakan cukup dengan memanfaatkan fasilitas pada Microsoft Excel. 
Pendalaman materi terkait aplikasi manajemen sitasi juga kurang diminati responden. Hanya $10 \%$ responden yang menyatakan sangat penting dan $40 \%$ responden yang menyatakan penting mempelajari aplikasi manajemen sitasi seperti Mendeley, EndNote, dan Refworks. Setengah dari responden diketahui dari survey tidak/kurang menganggap penting mendalami pengetahuan terkait pencatatan sitasi dan referensi ini. Responden sebagian besar masih terbiasa melakukan sitasi dengan cara manual. Ada sebagian yang melakukan manajemen referensi memanfaatkan fasilitas yang disediakan Microsoft Word dan ada sebagian kecil yang sama sekali tidak menggunakan aplikasi manejemen referensi.

Responden yang menganggap pemanfaatan manajemen referensi tidak penting dipelajari, juga sejalan dengan jawaban untuk pertanyaan terkait jurnal elektronik dan penelusuran bahan pustaka. Sebagian besar responden menjawab bahwa materi terkait e-journal dan penelusuran bahan pustaka tidak penting dimasukkan dalam bahan ajar MK TIK untuk guru bahasa. Responden berasumsi bahan pustaka yang bisa menjadi rujukan cukup dari buku atau media/jurnal cetak yang biasa ditemukan di lingkungan responden. Responden sebagian besar belum sepenuhnya menyadari bahwa pada era disrupsi informasi ini, sediaan bahan pustaka sebagai sumber rujukan teori sangat melimpah dalam bentuk data digital. Kondisi ini tentu tidak produktif dalam pengembangan akademik mahasiswa/guru, terutama dalam konteks penghargaan atas karya intelektual orang lain.

Lemahnya kesadaran akan penghargaan kekayaan intelektual juga terlihat dari pendapat responden bahwa materi uji kemiripan (similarity check) dianggap sangat penting dipelajari hanya oleh $10 \%$ responden saja $40 \%$ lainnya menganggap penting. Responden umumnya kurang menyadari bahwa isu plagiarisme dan penghargaan terhadap kekayaan intelektual saat ini menjadi isu sentral dalam dunia akademis. Kebijakan melakukan uji kemiripan telah dilakukan oleh semua terbitan berkala ilmiah, juga diberlakukan oleh hampir semua perguruan tinggi. Demikian pun saat naik pangkat, diberlakukan uji kemiripan terhadap karya ilmiah yang diajukan sebagai salah satu dokumen kelengkapan.

Pemanfaatan aplikasi pengembangan pembelajaran bauran (blended learning) Zoho dan pemanfaatan blog (wordpress dan blogspot) juga kurang diminati. Responden mengenali Zoho sebagai penyedia aplikasi presensi saja. Oleh karenanya guru merasa tidak penting mendalami fasilitas dalam aplikasi tersebut. Pada sisi lain, responden guru juga menyampaikan lebih penting mengembangkan bahan ajar teks yang didistribusikan dalan bentuk digital (.pdf) daripada disajikan dalam blog. Menurut responden, materi yang disajikan dalam blog rawan di contek.

\section{Pembahasan}

Analisis data menghasilkan peta kebutuhan materi ajar MK TIK untuk Guru Bahasa pada mata kuliah yang disajikan dalam kurikulum Program Magister (S2) Pendidikan Bahasa Indonesia FKIP Universitas Bengkulu. Secara umum pilihan topik yang diinginkan guru dilatar-belakangi oleh kebutuhan profesional mereka dan pengalaman mereka mengajar responden. Topik yang mereka pilih/usulkan/sarankan adalah program aplikasi yang pernah/sedang digunakan namun belum maksimal, misalnya: aplikasi Microsoft Office berbagai versi yang sudah biasa mereka gunakan dalam beraktivitas sehari-hari, yang sudah sangat diakrabi responden sejak jenjang 
sekolah dasar/menengah. Namun demikian, walapun sudah digunakan sudah sejak lama, masih banyak fitur yang belum diketahui dan belum dimanfaatkan.

Pada sisi lain, dari wawancara mendalam diketahui bahwa hampir semua perangkat lunak Microsoft Office yang terinstall pada komputer responden, ternyata bukan perangkat lunak resmi yang berlisensi. Responden merasa hal demikian bukan sebuah tindakan pelanggaran hak atas kekayaan intelektual. Pada saat ditawarkan penggunaan aplikasi perkantoran yang bersifat gratis, untuk menghindari pelanggaran hak cipta, responden kurang tertarik. Program aplikasi perkantoran dimaksud seperti WPS Office, Open Office, atau Libre Office. Semua responden menyatakan tidak penting untuk mempelajari WPS Office, Open Office, atau Libre Office.

Program aplikasi lain yang dibutuhkan guru responden untuk dimaksukkan sebagai bahan ajar MK TIK untuk Guru Bahasa berdasarkan pengalaman empiris adalah Zoom Cloud Meeting. Zoom Meeting sangat dibutuhkan/sangat membantu guru responden melaksanakan pembelajaran tatap muka maya, terutama untuk pembelajaran dalam jaringan (daring/online). Zoom Meeting merupakan salah satu platform rapat dalam jaringan (online meeting) yang banyak dipilih oleh guru. Platform pertemuan dalam jaringan lmisalnya Google Meet, kurang diminati oleh responden. Senada dengan aplikasi perkantoran, media presentasi yang dipilih hampir semua responden adalah Microsoft Power Point, karena perangkat lunak inilah yang sudah sangat dikenal. Pada saat diberi pilihan Prezi sebagai alternatif media presentasi yang dipelajari, responden cenderung menolak. Hanya sebagian kecil responden yang menyepakati Prezi dipelajari, dengan alasan aplikasi ini berat dan rumit. Responden lebih mengharapkan pendalaman kustomisasi pengaya Power Point yang dipelajari dan latihkan.

Media pembelajaran berbasis TIK lain yang ditawarkan kepada responden yakni Sparkol VideoScribe, Media Virtual Reality, maupun Augmented Reality untuk Pembelajaran, juga tidak disepakati sebagian besar responden untuk disajikan dalam MK TIK untuk Guru Bahasa. Alasan bahwa dasar pengetahuan mereka terkait TIK yang tidak memadai menjadi latar belakang mereka menganggap dua media pembelajaran tersebut penting dipelajari. Responden juga menganggap penggunaan sistem manajemen pembelajaran (learning magement system) berbasis Moodle tidak penting dipelajari. Responden masih merasa asing dengan LMS. Fasilitas yang disediakan Google, yang sudah sangat dikenali hanya surel berekstensi Gmail. Fasilitas lain misalnya a. Google Form; b. Google Doc; c. Google Drive; d. Google Classroom; e. Google Photos; f. Google Meet, belum akrab dan dimanfaatkan secara efektif oleh responden.

Survey juga menunjukkan perangkat lunak pengolah data kuantitatif dalam penelitian seperti SPSS atau minitab kurang diminati responden Alasan yang disampaikan, dalam dunia keguruan sebagian besar penelitian dilaksanakan dalam desain penelitian kualitatif. Seandainya membutuhkan pengolahan statistik sederhana, responden menyatakan cukup dengan memanfaatkan fasilitas pada Microsoft Excel.

Pendalaman materi terkait aplikasi manajemen sitasi juga kurang diminati responden. Sedikit responden yang menyatakan penting mempelajari aplikasi manajemen sitasi seperti Mendeley, EndNote, dan Refworks. Responden sebagian besar masih terbiasa melakukan sitasi dengan cara manual. Responden yang menganggap pemanfaatan manajemen referensi tidak penting dipelajari, juga sejalan dengan jawaban untuk pertanyaan terkait jurnal elektronik dan penelusuran bahan pustaka. Sebagian besar responden menjawab bahwa materi terkait e-journal 
dan penelusuran bahan pustaka tidak penting dimasukkan dalam bahan ajar MK TIK untuk guru bahasa. Responden berasumsi bahan pustaka yang bisa menjadi rujukan cukup dari buku atau media/jurnal cetak yang biasa ditemukan di lingkungan responden. Responden sebagian besar belum sepenuhnya menyadari bahwa pada era disrupsi informasi ini, sediaan bahan pustaka sebagai sumber rujukan teori sangat melimpah dalam bentuk data digital. Kondisi ini tentu tidak produktif dalam pengembangan akademik mahasiswa/guru, terutama dalam konteks penghargaan atas karya intelektual orang lain.

Lemahnya kesadaran akan penghargaan kekayaan intelektual juga terlihat dari pendapat responden bahwa materi uji kemiripan (similarity check) dianggap sangat penting dipelajari. Responden umumnya kurang menyadari bahwa isu plagiarisme dan penghargaan terhadap kekayaan intelektual saat ini menjadi isu sentral dalam dunia akademis. Kebijakan melakukan uji kemiripan telah dilakukan oleh semua terbitan berkala ilmiah, juga diberlakukan oleh hampir semua perguruan tinggi. Demikian pun saat naik pangkat, diberlakukan uji kemiripan terhadap karya ilmiah yang diajukan sebagai salah satu dokumen kelengkapan.

\section{Simpulan}

Materi yang dibutuhkan dalam bahan ajar Mata Kuliah Teknologi Informasi dan Komunikasi untuk Guru Bahasa pada Program Magister (S2) Pendidikan Bahasa Indonesia FKIP Universitas Bengkulu meliputi: A. Materi yang diinginkan responden: 1) Microsoft Office: Word, Excel, dan Power Point; 2) Aplikasi yang disediakan oleh Google: a. Google Mail, b. Google Form, c. Google Doc, d. Google Drive, e. Google Classroom, f. Google Photos, g. Youtube, dan h. Google Meet; dan 3) Cloud Zoom Meting. B. Materi yang dibutuhkan: program aplikasi manajemen aplikasi (Mendeley, RefWorks, dan Zootero), Pengolahan data statistik (SPSS), penelusuran bahan pustaka dan e-journal.

\section{Saran}

Tindak lanjut dari penelitian ini adalah revisi bahan ajar modul mata kuliah TIK untuk Guru Bahasa yang telah terbit pada tahun 2018 ISBN 978-623-7074-09-0. Penelitian lanjutan bisa dilakukan untuk melihat efektifitas pemanfaatan buku teks dimaksud untuk perkuliahan

\section{Ucapan Terima kasih}

Penulis menyampaikan apresiasi dan terima kasih kepada FKIP Universitas Bengkulu yang mendukung penelitian ini dengan menyediakan anggaran melalui RBA FKIP Universitas Bengkulu dengan nomor kontrak Nomor Kontrak: 9204/UN30.7/HK/2020 tanggal 29 Juli 2020.

\section{Daftar Pustaka}

Graves, K. 2000. Designing Language Discourses. Heinle \& Heinle Publisher.

Hartanto, A. 2018. Making Indonesia 4.0.

Hutchinson, T., \& Alan, W. 1987. English for Specific Purposes. Cambridge University Press. Hyland, K. 2003. Second Language Writing. Cambridge University Press.

Jack C. Richards. 2000. Curriculum Development in Language Teaching. Cambridge University Press. 
Kasali, R. 2018. Disruption (9 ed.). Gramedia.

Matthew B. Miles, Huberman, A. M., \& Saldaña, J. 2014. Qualitative data analysis: a methods sourcebook (Third Edit). SAGE Publications, Inc.

Nation, I. S. P., \& McAllister, J. 2010. Language Curriculum Design (hal. 1-3). Routledge.

Putri, G. S. 2020. WHO Resmi Sebut Virus Corona Covid-19 sebagai Pandemi Global. Kompas. https://www.kompas.com/sains/read/2020/03/12/083129823/who-resmi-sebut-viruscorona-covid-19-sebagai-pandemi-global

Risdianto, E. 2019. Analisis Pendidikan Indonesia di Era Revolusi Industri 4.0. academia.edu.

RISTEKDIKTI. (2018). Pengembangan Iptek dan Pendidikan Tinggi di Era Revolusi Industri 4.0. RISTEKDIKTI.

Satya, V. E. 2018. STRATEGI INDONESIA MENGHADAPI INDUSTRI 4.0.

Stufflebeam, D. L., McCormick, C. H., Brinkerhoff, R. O., \& Nelson, C. O. (1985). Conducting Educational Needs Assessments. In Conducting Educational Needs Assessments. Kluwer Nijhoff Publishing. https://doi.org/10.1007/978-94-011-7807-5

Wibawa, S. 2018. Pendidikan dalam Era Revolusi Industri 4.0. https://mpd.ustjogja.ac.id/images/upload/file/UST Pendidikan di Era Revolusi Industri 4.0.pdf

Yahya, M. 2018. ERA INDUSTRI 4.0: TANTANGAN DAN PELUANG PERKEMBANGAN PENDIDIKAN KEJURUAN INDONESIA. 